\title{
CES 造耐震壁のせん断伝達メカニズムに及ぼす壁板位置の影響 EFFECT OF WALL PANEL ARRANGEMENT ON SHEAR TRANSFERRING MECHANISMS OF CES SHEAR WALLS
}

\author{
鈴木 卓*, 倉本 洋**, 松井智哉*** \\ Suguru SUZUKI, Hiroshi KURAMOTO and Tomoya MATSUI
}

\begin{abstract}
In this study, shear transferring mechanisms of CES shear walls with eccentrically arranged wall panel were examined by three dimensional FEM analysis. The analytical parameters are position of the wall panel and shear span ratio. The analytical results for the shear force versus drift angle relationships of the CES shear walls showed good agreements with experimental results. Thus the validity of the assumed analytical modeling was confirmed. It was indicated through the analysis that the position of wall panel affected little on the strength of the walls. However, different stress contribution in the boundary column subjected to compression was observed with the difference of wall panel arrangement, after the maximum shear strength of the walls. It was also confirmed that the deformability of the walls were affected by the position of the wall panel.
\end{abstract}

Keywords: CES Shear walls, FRC, Shear Span Ratio, Eccentric Shear Walls, FEM Analysis CES 造而震壁，繊維補強コンクリート，せん断スパン比，偏心壁，FEM解析

\section{1. はじめに}

現在, CES 構造 (Concrete Encased Steel) に関する研究開発が進 められており, CES 構造部材の構造性能が徐々に明らかにされつつ ある ${ }^{1)-3)}$ 。本研究において検討対象としている CES 造耐震壁に関し ても, 壁縦筋の梁への定着を簡略化した CES 造耐震壁の静的加力実 験に基づいて破壊性状，耐荷性能および変形性能についての検討を 行い，壁縦筋を梁へ定着させたものと同等以上の構造性能を有寸る ことが示されている ${ }^{4)}$ 。らに, これらの耐震壁を対象に 2 次元 FEM 解析が実施され, 内部応力状態から CES 造耐震壁の耐荷性能に及ぼ 寸壁縦筋の定着の影響は小さいことが明らかにされている ${ }^{5)}$

一方で，建築物の外部に面する耐震壁は壁板が柱に偏心して取り 付くことが多い。CES 造耐震壁において壁板が柱に偏心して取り付 いた場合，側柱の内蔵鉄骨による壁板への拘束効果の低下が懸念さ れる。それにより，従来検討してきた無偏心壁配置の CES 造耐震壁 の場合と比較して耐荷性能の低下寸る可能性があり, 壁板が偏心し て取り付いた CES 造耐震壁の耐荷性能, 変形性能および破壊性状を 把握する必要がある。

このような背景から，筆者らは壁板が柱に偏心して取り付く CES 造耐震壁の静加力実験を実施し, 偏心壁配置耐震壁と無偏心壁配置 耐震壁の最大耐力は同等になることを示した ${ }^{6}$ 。ししいながら，破 壊状況について見ると, せん断破壞先行型試験体では偏心壁試験体 の損傷箇所は無偏心壁試験体と異なり, 曲げ降伏先行型試験体では,
偏心壁試験体の損傷は無偏心壁試験体と比べて早期に生じる傾向が 認められ，偏心壁配置耐震壁と無偏壁配置耐震壁の応力伝達メカ二 ズムは異なることが考えられる。

そこで本研究では, CES 造耐震壁の 3 次元 FEM 解析を実施し, FEM 解析の仮定およびモデル化の妥当性を検証する。さらに，壁板位置 を変数としたパラメトリック解析を行い, 壁板位置が CES 造耐震壁 の応力伝達メカニズムに及ぼす影響に関する検討結果を述べる。

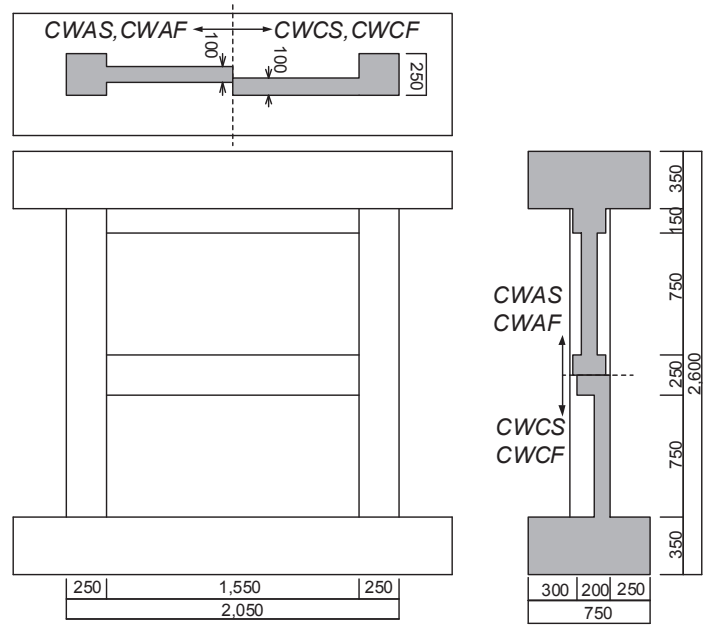

図 1 試験体形状

\footnotetext{
${ }^{*}$ 大阪大学大学院工学研究科地球総合工学専攻 大学院生 日本学術振興会 特別研究員 DC

** 大阪大学大学院工学研究科地球総合工学専攻 教授・博士 (工学)

*** 豊橋技術科学大学大学院工学研究科 建築・都市システム学系 准教授・博士 (工学

Div. of Global Architectural, Graduate School of Eng., Osaka Univ. JSPS Research Fellow

Prof., Div. of Global Architecture, Graduate School of Eng., Osaka Univ., Dr. Eng.

Assoc. Prof., Dept. of Architecture \& Civil Engineering, Graduate School of Engineering, TUT, Dr. Eng.
} 


\section{2. 解析対象試験体の概要}

\section{1 試験体概要}

試験体は，中高層壁フレーム建築物における連層耐震壁の下部 2 層を想定した実大の $1 / 3$ スケールのもの 4 体である。試験体の形状 を図 1 に,配笳を図 2 に, および試験体概要を表 1 にそれぞれ示す。 耐震壁は階高が $1,000 \mathrm{~mm}$ ，柱中心間距離が $1,800 \mathrm{~mm}$ ，壁厚が $100 \mathrm{~mm}$ および側柱断面が $250 \mathrm{~mm}$ 角である。また，壁梁の幅およびせいは それぞれ $200 \mathrm{~mm}$ および $250 \mathrm{~mm}$ である。図 2 に示すように本実験の 試験体では, 壁縦筋を梁内に定着せず壁板内でフックを設けてある。 また，無偏心壁試験体の壁横筋は側柱内蔵鉄骨ウェブに溶接して設 置しているのに対して，偏心壁試験体では，耐震壁の壁板は付帯柱 に偏心して取り付け, 壁横笳は側柱内で 90 度フックにより定着させ た。

実験変数はせん断スパン比（M/(QL)， L ：壁全せい）と壁板の偏 心配置の有無である。試験体 CWAS および CWCS ではせん断スパ ン比を 1.1 とし, 試験体 CWAF および CWCF ではせん断スパン比を 1.65 として，それぞれせん断破壊先行型および曲げ降伏先行型の試 験体となるように計画した。また，試験体 CWAS および CWAF は 無偏心壁試験体とし, 試験体 CWCS および CWCF は壁板が柱に偏 心して取り付く偏心壁試験体とした。

\section{2 使用材料}

表 2 に繊維補強コンクリートの材料特性を, 表 3 に鉄骨および鉄 筋の材料特性をそれぞれ示す。コンクリートの打設は, 基礎スタブ, 壁部 1 層（１層梁上端まで），壁部 2 層（上部スタブ下端まで）， および上部スタブの 4 回に分けて行った。また，基礎スタブおよび 上スタブを除く試験体の柱, 梁および壁板のコンクリートは䋊維補 強コンクリートを使用している。表 4 に繊維補強コンクリートに使 用した繊維の材料特性を示す。繊維は直径が $0.66 \mathrm{~mm}$ ，長さが $30 \mathrm{~mm}$ のビニロンファイバー（RF4000）で体積混入率は $1.0 \%$ である。

\section{3 載荷方法}

載荷装置を図 3 に示す。試験体は反カフレームに PC 鋼棒で固定 し, 水平力の正負繰り返し載荷は反力壁に取り付けた水平オイルジ ヤッキ $(2,000 \mathrm{kN})$ によって行った。さらに, 反力フレームに取り付 けた 2 台の鉛直オイルジャッキ（各 $2,000 \mathrm{kN})$ により，無偏心壁試 験体では $\mathrm{N}=1,260 \mathrm{kN}$ ，偏心壁試験体では $\mathrm{N}=1,135 \mathrm{kN}$ の一定軸力（柱 軸力比 $\mathrm{N} / \mathrm{N}_{0}=0.2, \mathrm{~N}_{0}$ ：鉄骨を含む軸耐力）を試験体頂部に作用させ ると同時に，せん断スパン比が 1.1 もしくは 1.65 となるように作用 せん断力に対応させて当該鉛直ジャッキを制御することで試験体頂 部に付加モーメントを作用させた。実験は試験体頂部の水平変位 $(\delta)$ を計測位置の高さ $(\mathrm{H}=2,050 \mathrm{~mm})$ で除した相対部材角 $\mathrm{R}=\delta / \mathrm{H}$ で西側 方向載荷を正載荷として制御した。

\section{4 実験結果の概要}

図 4 に各試験体のせん断力一部材角関係を, 図 5 に各試験体南面 の最終破壊状況を示す。

せん断破壊先行型試験体 CWAS および CWCS の最大耐力ほほぼ 同等の值が記録された。その後, 偏心壁試験体 CWCS は無偏心壁試 験体 CWAS と比較して急激な耐力低下が生じている。無偏心壁試験 体 CWAS では, 壁縦筋の定着のない 1 層壁板と梁の境界でずれが生 じており, それに伴い 1 層壁板の上隅角部に損傷が集中した。一方, 偏心壁試験体 CWCS では，無偏心壁試験体 CWAS と同様に壁縦筋

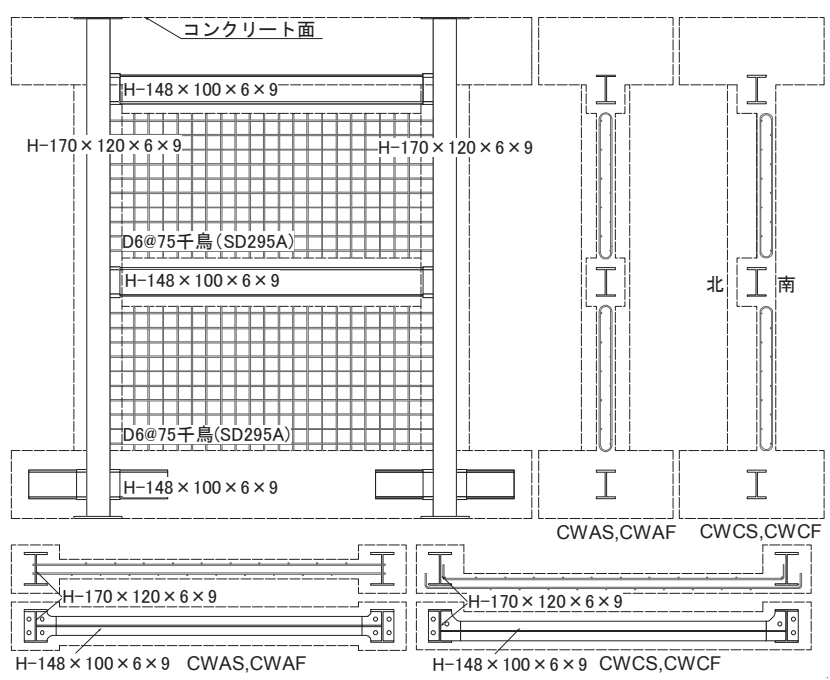

図 2 試験体配筋図

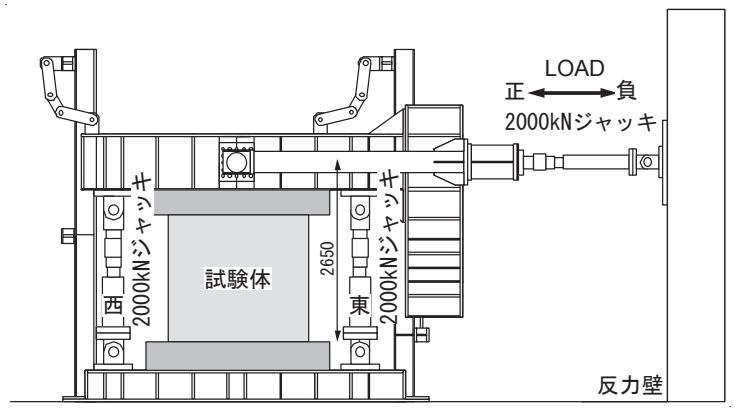

図 3 載荷装置

表 1 試験体概要

\begin{tabular}{|c|c|c|c|c|c|}
\hline \multicolumn{2}{|c|}{ 試験体 } & CWAS & CWAF & CWCS & CWCF \\
\hline \multirow{2}{*}{ 柱 } & $B \times D$ & \multicolumn{4}{|c|}{$250 \times 250(\mathrm{~mm})$} \\
\hline & 鉄骨 & \multicolumn{4}{|c|}{$\mathrm{H}-170 \times 120 \times 6 \times 9\left({ }_{s} \mathrm{p}=4.9 \%\right)$} \\
\hline \multirow{2}{*}{ 梁 } & $\mathrm{B} \times \mathrm{D}$ & \multicolumn{4}{|c|}{$200 \times 250(\mathrm{~mm})$} \\
\hline & 鉄骨 & \multicolumn{4}{|c|}{$\mathrm{H}-148 \times 100 \times 6 \times 9\left({ }_{g} p=5.2 \%\right)$} \\
\hline \multirow{3}{*}{ 壁 } & 壁厚 & \multicolumn{4}{|c|}{$100(\mathrm{~mm})$} \\
\hline & 縦筋 & \multicolumn{4}{|c|}{ D6@75 千鳥 ( } \\
\hline & 横筋 & \multicolumn{4}{|c|}{ D6@75 千鳥 $\left({ }_{w} p=0.42 \%\right)$} \\
\hline \multicolumn{2}{|c|}{ 軸力 } & \multicolumn{2}{|c|}{$1,260(\mathrm{kN})$} & \multicolumn{2}{|c|}{$1,135(\mathrm{kN})$} \\
\hline \multicolumn{2}{|c|}{ 壁板の偏心 } & \multicolumn{2}{|c|}{ 無偏心 } & \multicolumn{2}{|c|}{ 偏心 } \\
\hline \multicolumn{2}{|c|}{ せん断スパン比 } & 1.1 & 1.65 & 1.1 & 1.65 \\
\hline
\end{tabular}

表 2 繊維補強コンクリートの材料特性

\begin{tabular}{c|c||c|c|c|c}
\hline \multicolumn{2}{c|}{ 試験体 } & $\sigma_{B}(\mathrm{MPa})$ & $E_{C}(\mathrm{GPa})$ & $\varepsilon_{C O}(\mu)$ & $\sigma_{c r}(\mathrm{MPa})$ \\
\hline \hline \multirow{2}{*}{$C W A S$} & 1 層 & 38.6 & 24.8 & 2814 & 2.99 \\
\cline { 2 - 6 } & 2 層 & 36.4 & 26.7 & 2550 & 2.53 \\
\hline \multirow{2}{*}{ CWAF } & 1 層 & 41.2 & 25.5 & 2457 & 3.03 \\
\cline { 2 - 6 } & 2 層 & 38.6 & 27.6 & 2423 & 2.55 \\
\hline \multirow{2}{*}{ CWCS } & 1 層 & 32.3 & 23.0 & 2868 & 2.52 \\
\cline { 2 - 6 } & 2 層 & 34.2 & 25.1 & 2742 & 2.65 \\
\hline \multirow{2}{*}{ CWCF } & 1 層 & 33.8 & 27.1 & 2377 & 2.41 \\
\cline { 2 - 6 } & 2 層 & 34.9 & 28.4 & 2321 & 2.54 \\
\hline
\end{tabular}

$\sigma_{B}$ : 圧縮強度, $E_{C}$ : 弾性係数, $\varepsilon_{C O}$ : 圧縮強度時ひずみ, $\sigma_{c r}$ : 引張強度

表 3 鉄骨および鉄筋の材料特性

\begin{tabular}{|c|c|c|c|c|c|}
\hline 試験体 & \multicolumn{2}{|c|}{ 種別 - 使用箇所 } & $\sigma_{y}(\mathrm{MPa})$ & $E_{S}(\mathrm{GPa})$ & $\sigma_{u}(\mathrm{MPa})$ \\
\hline CWAS, CWAF & \multirow{3}{*}{$\begin{array}{c}\text { PL-6 ウェブ } \\
\text { (SS400) }\end{array}$} & - & 260 & 190 & 420 \\
\hline \multirow{2}{*}{ CWCS, CWCF } & & 柱 & 300 & 197 & 422 \\
\hline & & 梁 & 338 & 201 & 457 \\
\hline CWAS, CWAF & \multirow{3}{*}{$\begin{array}{l}\text { PL-9 フランジ } \\
\text { (SS400) }\end{array}$} & - & 282 & 197 & 418 \\
\hline \multirow{2}{*}{ CWCS, CWCF } & & 柱 & 297 & 209 & 442 \\
\hline & & 梁 & 317 & 197 & 448 \\
\hline CWAS & \multirow{2}{*}{\multicolumn{2}{|c|}{$\begin{array}{c}\text { D6 壁補強筋 } \\
\text { (SD295A) }\end{array}$}} & 345 & 190 & 501 \\
\hline CWCS, CWCF & & & 396 & 192 & 518 \\
\hline
\end{tabular}

$\sigma_{y}$ : 降伏強度, $E_{S}$ : 弾性係数, $\sigma_{u}$ : 引張強度

表 4 繊維の材料特性

\begin{tabular}{c||c|c|c|c|c|c}
\hline 名称 & $\begin{array}{c}\text { 直径 } \\
(\mu)\end{array}$ & $\begin{array}{c}\text { 標準長 } \\
(\mathrm{mm})\end{array}$ & $\begin{array}{c}\text { 比重 } \\
\left(\mathrm{g} / \mathrm{cm}^{3}\right)\end{array}$ & $\begin{array}{c}\text { 引張強度 } \\
(\mathrm{MPa})\end{array}$ & $\begin{array}{c}\text { 切断伸度 } \\
(\%)\end{array}$ & $\begin{array}{c}\text { 弾性係数 } \\
(\mathrm{GPa})\end{array}$ \\
\hline \hline RF4000 & 660 & 30 & 1.3 & 900 & 9 & 23 \\
\hline
\end{tabular}




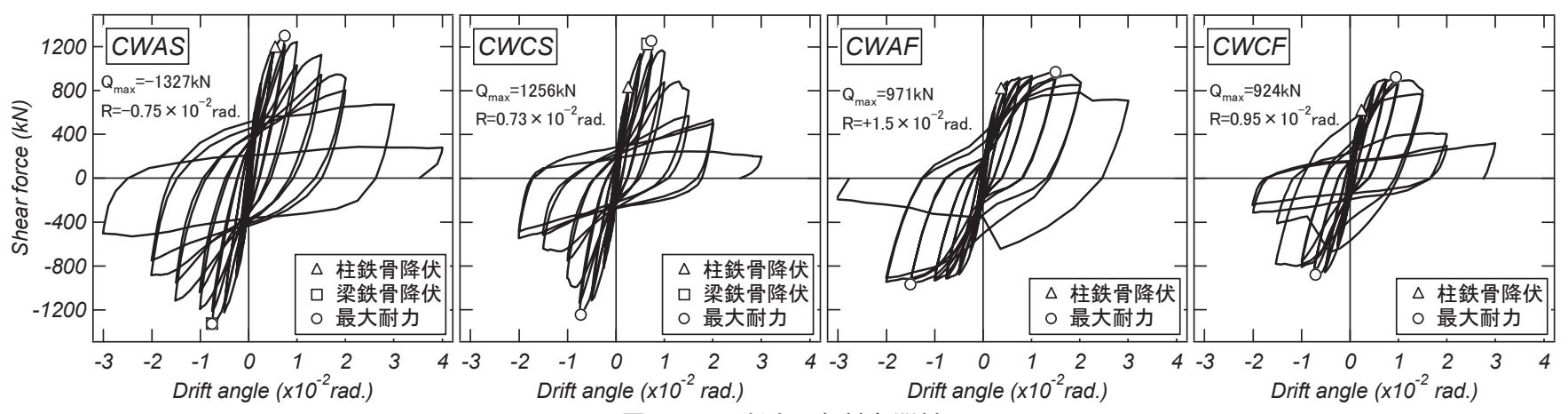

図 4 せん断力一部材角関係

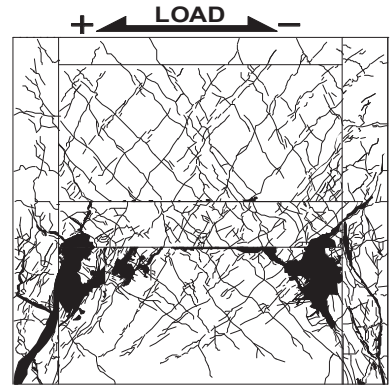

(a) CWAS

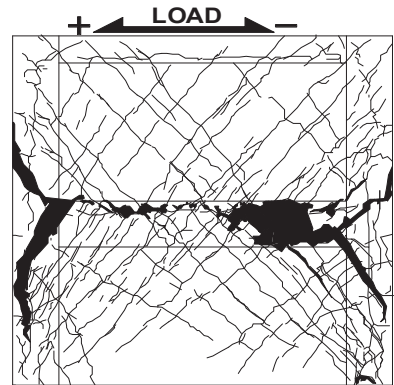

(b) CWCS

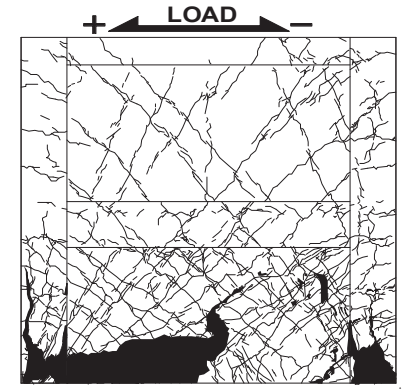

(c) CWAF

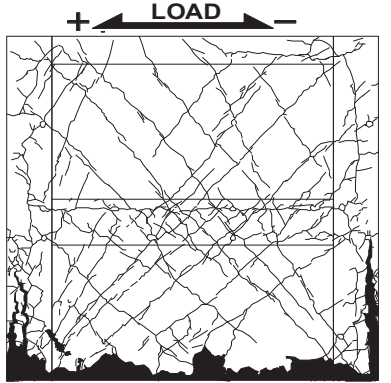

(d) CWCF

図 5 各試験体の最終破壊状況（南面）

の定着のない 1 層壁板と梁の境界でずれが生じ，その後， 1 層梁の せん断破壊が発生した。すなわち, 試験体 CWCS では図 2 に示すよ うに壁板は柱に偏心して取り付いていることと梁のかぶりコンクリ 一ト部分の剛性は低いことから, 1 層梁のかぶり部分に損傷が集中 し, 試験体 CWAS と比べて変形性能が低下したものと考えられる。 曲げ降伏先行型試験体においても, 試験体 CWAF および CWCF の最大耐力はほぼ同等の值が記録された。最大耐力後の挙動を比較 すると, 偏心壁試験体および無偏心壁試験体の変形性能に違いが見 られる。試験体 CWAF では, $\mathrm{R}=2.0 \times 10^{-2} \mathrm{rad}$.の載荷サイクルにおいて 脚部コンクリートの圧壊に伴う耐力低下が生じたが, 試験体 CWCF では, $\mathrm{R}=1.5 \times 10^{-2} \mathrm{rad}$.の載荷サイクルで 1 層壁板の東西側柱付近の脚 部コンクリートの圧壊に伴う耐力低下が生じた。試験体 CWCF では, 壁板が偏心しているため圧縮側柱コンクリートは応力をあまり負担 せず，圧縮側壁板の脚部コンクリートの損傷が早期に生じたと考え られ，変形性能に影響を及ぼしたと考えられる。

以上より, 破壊形式に拘わらず偏心壁試験体の耐荷性能は無偏心 壁試験体と同等であるといえる。また, 偏心壁試験体の変形性能は 無偏心壁試験体と比べて低下する傾向にある。

\section{FEM 解析}

\section{1 解析概要}

解析対象試験体は 2 章で示した無偏心壁試験体 CWAS および $\mathrm{CWAF}^{4)}$ と偏心壁試験体 $\mathrm{CWCS}$ および $\mathrm{CWCF}^{6}$ である。さらに, これ ら偏心壁試験体と無偏心壁試験体の中間に壁板が位置する解析モデ ル CWES および CWEF についても解析を実施する。なお, 小偏心 壁モデル CWES および CWEF では, 壁板は柱に偏心して取り付い ているものの, 無偏心壁試験体と同様に壁板は側柱の内蔵鉄骨によ る拘束効果の影響を受けるように要素を分割した。表 5 に試験体の 解析変数を示す。
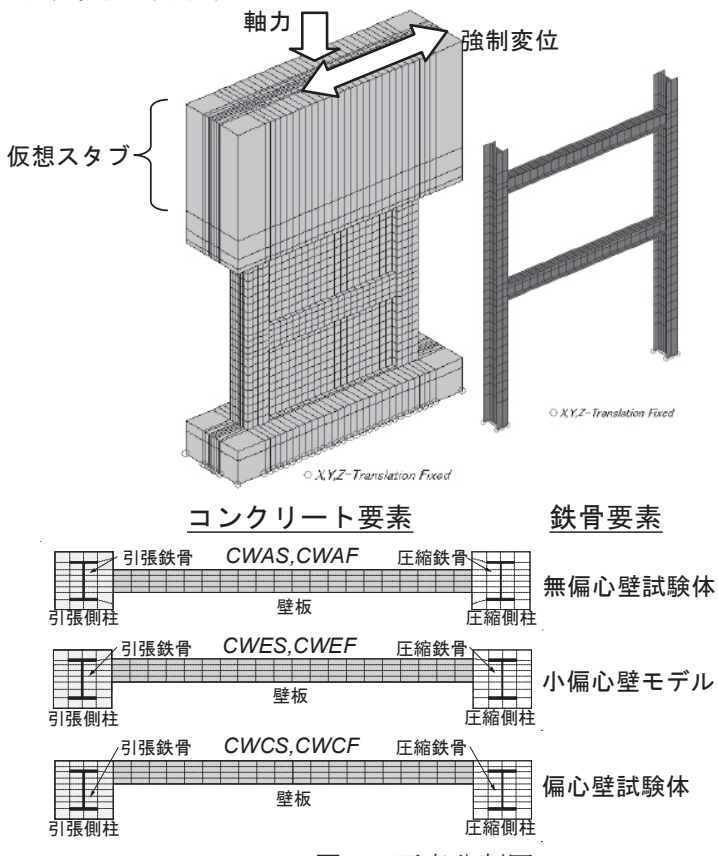

図 6 要素分割図

図 6 に要素分割図を示す。コンクリートの要素数は, 無偏心壁試 験体が 5496, 小偏心壁モデルが 5616 および偏心壁モデルが 6108 で ある。本解析では実験と同様のせん断スパン比 1.1 および 1.65 とす るため, 試験体の上スタブから実験における想定加力高さまで仮想 スタブをコンクリートの 10 倍程度の硬さの弾性体で定義し, 仮想ス タブ上端に実験と同様の部材角となるよう強制変位を与えた。軸力 は仮想スタブ上端において一定軸力を与えた。また，下スタブ下端 のコンクリートおよび鉄骨要素の節点は完全固定（水平，鉛直およ び面外方向の自由度を拘束）とした。解析は変位制御による正負交 番繰返し載荷とし， $\mathrm{R}=1.0 \times 10^{-2} \mathrm{rad}$.の第 2 サイクルまで示した。な お, 解析は 3 次元非線形解析ソフト”FINAL" "7)を使用した。 
表 5 解析変数

\begin{tabular}{|c|c|c|}
\hline 変数 & 壁板の偏心 & せん断スパン比 \\
\hline CWAS & $\begin{array}{l}\text { 無偏心 } \\
\end{array}$ & \multirow{3}{*}{$\begin{array}{c}1.1 \\
\text { (せん断破壊先行型） }\end{array}$} \\
\hline CWES & 小偏心 & \\
\hline CWCS & 偏心 & \\
\hline CWAF & 無偏心 & \multirow{3}{*}{$\begin{array}{c}1.65 \\
\text { （曲げ降伏先行型） }\end{array}$} \\
\hline CWEF & 小偏心 & \\
\hline CWCF & 偏心 & \\
\hline
\end{tabular}

表 6 繊維補強コンクリートの材料特性（小偏心壁モデル）

\begin{tabular}{c|c||c|c|c}
\hline \multicolumn{2}{c||}{ 試験体 } & $\sigma_{B}(\mathrm{MPa})$ & $E_{C}(\mathrm{GPa})$ & $\varepsilon_{C 0}(\mu)$ \\
\hline \hline CWES & 1 層 & 36.0 & 26.0 & 2600 \\
\cline { 2 - 5 } CWEF & 2 層 & 36.0 & 26.0 & 2600 \\
\hline
\end{tabular}

$\sigma_{B}:$ 圧縮強度, $E_{C}:$ 弾性係数, $\varepsilon_{C O}:$ 圧縮強度時ひずみ

表 7 鉄骨および鉄筋の材料特性（小偏心壁モデル）

\begin{tabular}{c||c|c|c|c}
\hline 試験体 & 種別・使用箇所 & $\sigma_{y}(\mathrm{MPa})$ & $E_{S}(\mathrm{GPa})$ \\
\hline \hline \multirow{4}{*}{ CWES, CWEF } & $\mathrm{PL}-6$ ウェブ & 柱 & 280 & 194 \\
\cline { 2 - 5 } & \multirow{2}{*}{$\mathrm{P}-9$ フランジ } & 柱 & 299 & 196 \\
\cline { 2 - 5 } & $\mathrm{PL}$ & 290 & 203 \\
\cline { 2 - 5 } & \multicolumn{2}{|c|}{$\mathrm{D} 6$ 壁補強筋 } & 300 & 197 \\
\hline
\end{tabular}

$\sigma_{y}:$ 降伏強度, $E_{s}$ : 弾性係数

\section{2 コンクリートのモデル化}

コンクリートは変位関数が 1 次となる 8 節点アイソパラメトリッ ク立体要素でモデル化し, 応力ーひずみ関係については, 圧縮側の 応力上昇域は修正 Ahmad モデル ${ }^{8)}$ とし, 軟化域はコンクリートの材 料試験を参考に図 7(a)に示寸多折線でモデル化した。引張側はひび 割れ発生までを線形で仮定し, ひび割れ発生後の軟化域は出雲らの 提案モデル ${ }^{9}$ を用いた。柱および梁要素では上記のモデルの係数 $\mathrm{c}=1.0$ としてひび割れ発生後に引張応力をほとんど負担しないもの とし，鉄筋がある壁板要素では $\mathrm{c}=0.2$ としてテンションスティフニ ングを考慮した（図 7(b)）。三軸応力下の破壊条件は Willam-Warnke

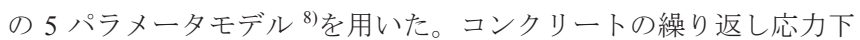
における履歴モデルは，除荷と再載荷過程における軟化挙動を考慮 した曲線モデル ${ }^{10)}$ を使用した (図 7(c))。ひび割れ後のせん断伝達モ デルは図 7(d)に示す Al-Mahaidi モデル ${ }^{11)}(\beta=1.0$ の場合) に対して, せん断伝達剛性がわずかに大きくなるように $\beta=0.8$ として多折線で モデル化した。また, 壁板のせん断補強筋は埋め込み鉄筋として要 素内に層状置換した。解析に用いた繊維補強コンクリートの材料特 性は表 2 の值を，鉄骨および鉄筋の材料特性は表 3 の值をそれぞれ 用いている。また，小偏心壁モデル CWES および CWEF の材料特 性については，無偏心壁試験体および偏心壁試験体の材料特性の平 均值とし，繊維補強コンクリートの材料特性は表 6 の值を，鉄骨お よび鉄筋の材料特性は表 7 の值をそれぞれ用いている。ただし，本 論で解析対象とした試験体では載荷前に初期ひび割れの発生が確認 されており，文献 12 )を参考に FRC の引張強度を $0.4 \mathrm{MPa}$ 一低減し た。

本論で解析対象としている試験体は壁縦筋の梁への定着を省略 (図 2 参照) しているため, 壁板と梁およびスタブの間に離散ひび

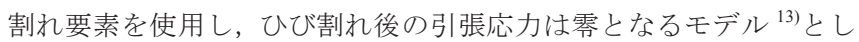
た。また, 離散ひび割れ要素のひび割れ面のせん断伝達特性は長沼

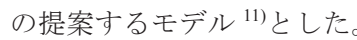

\section{2 鋼材のモデル化}

柱の鉄骨ウェブおよびフランジは面外曲げおよびせん断変形を考

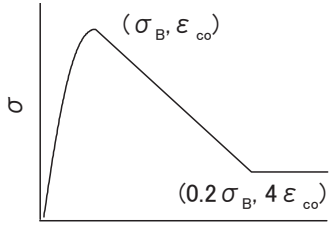

(a) 圧縮側モデル

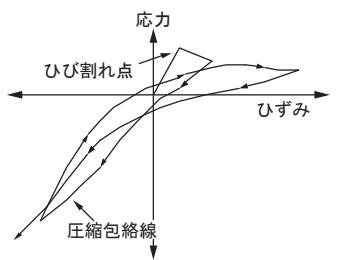

(c) 履歴特性

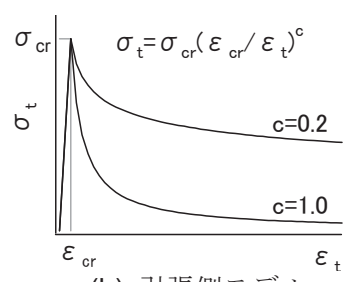

(b) 引張側モデル

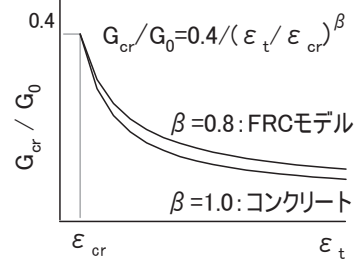

(d) せん断伝達モデル
図 7 コンクリートの材料モデル

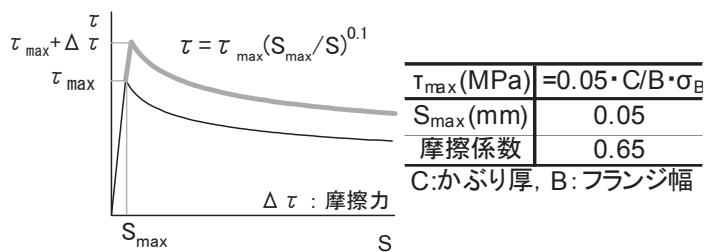

図 8 鉄骨とコンクリートの付着応力ーすべり関係

慮できる 4 節点積層シェル要素でモデル化し，梁の鉄骨ウェブおよ びフランジは 4 節点平面応力要素でモデル化した。鋼材の応力ーひ ずみ関係はバイリニアモデルで表し,履歴特性は等方硬化則とした。 鉄骨とコンクリートの間をフィルム要素で定義し，付着応力ーす心゙ り関係については, 最大付着応力点までを線形で仮定し, 最大付着 応力後の軟化域は文献 14)を参照しモデル化した。ここで最大付着 応力は $\tau_{\max }=0.05 \times \mathrm{C} / \mathrm{B} \times \sigma_{\mathrm{B}}\left(\mathrm{C}:\right.$ かぶり厚, $\mathrm{B}$ : フランジ幅, $\sigma_{\mathrm{B}}$ : コン クリート強度）とした ${ }^{15)}$ 。また, 面外圧縮力に伴う摩擦力の増大を 付着応力に加え，このときの摩擦係数は 0.65 とした (図 8 参照)。

\section{4. 解析結果}

\section{1 履歴特性}

図 9 に実験および解析におけるせん断力一部材角関係を示す。

全ての試験体の解析結果を見ると, 最大耐力後の耐力低下の挙動 は模擬できていない結果となっている。これは，鉄骨および鉄筋の 座屈挙動を模擬していないためと考えられる。しかしながら，す心゙ ての試験体において正載荷および負載荷ともに最大耐力の解析值は 実験值と比べて概放一致していることがわかる。履歴性状について 見ると，せん断破壊先行型試験体 CWAS および CWCS では，解析 結果は実験結果と比べて原点を指向する傾向が認められ，曲げ降伏 先行型試験体 CWAF および CWCF では, 解析結果は実験結果を精 度良く再現できている。

次に，図 9 に示す小偏心壁モデル CWES および CWEF について 着目すると，両解析モデルの最大耐力は無偏心壁試験体および偏心 壁試験体と比べてわずかに大きくなる傾向が認められた。しかしな がら，破壊形式に拘らず小偏心壁モデルのせん断力一部材角関係は 無偏心壁試験体および偏心壁試験体のものとほぼ同様の履歴性状と なる傾向が認められた。 

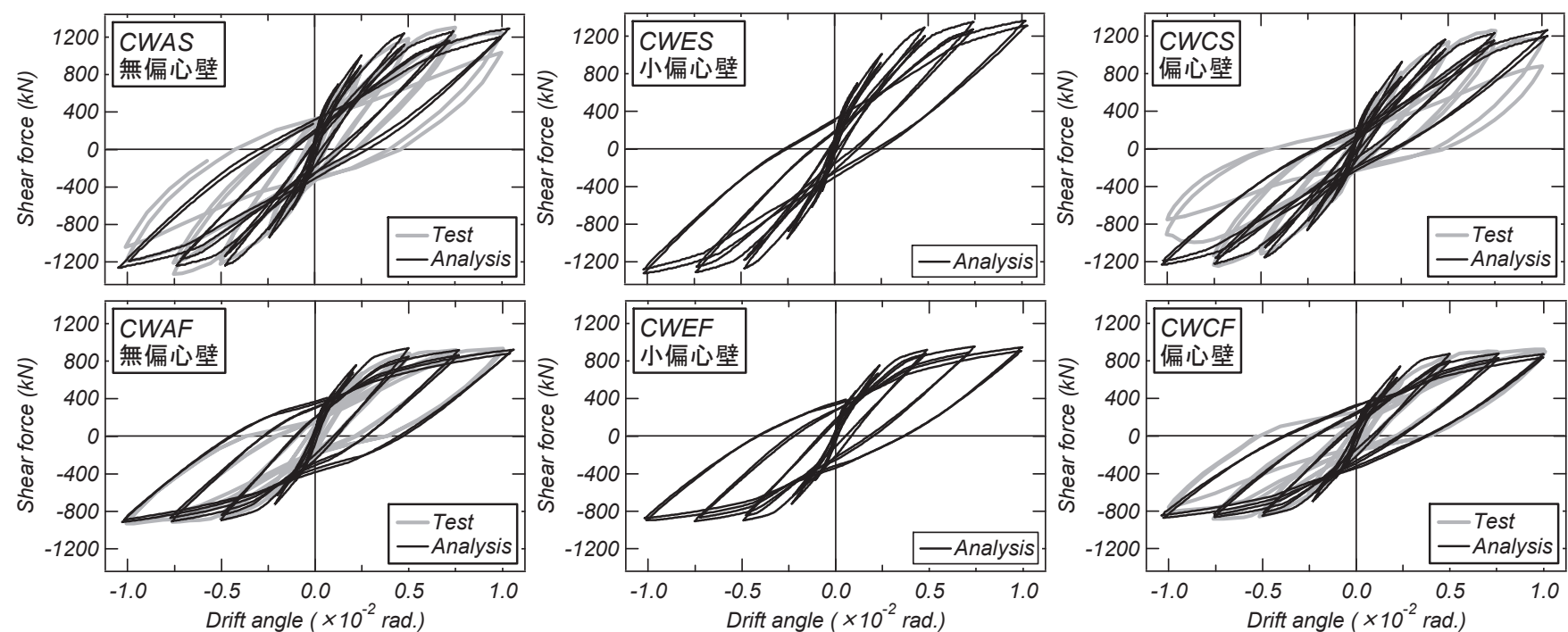

図 9 実験および解析におけるせん断力一部材角関係
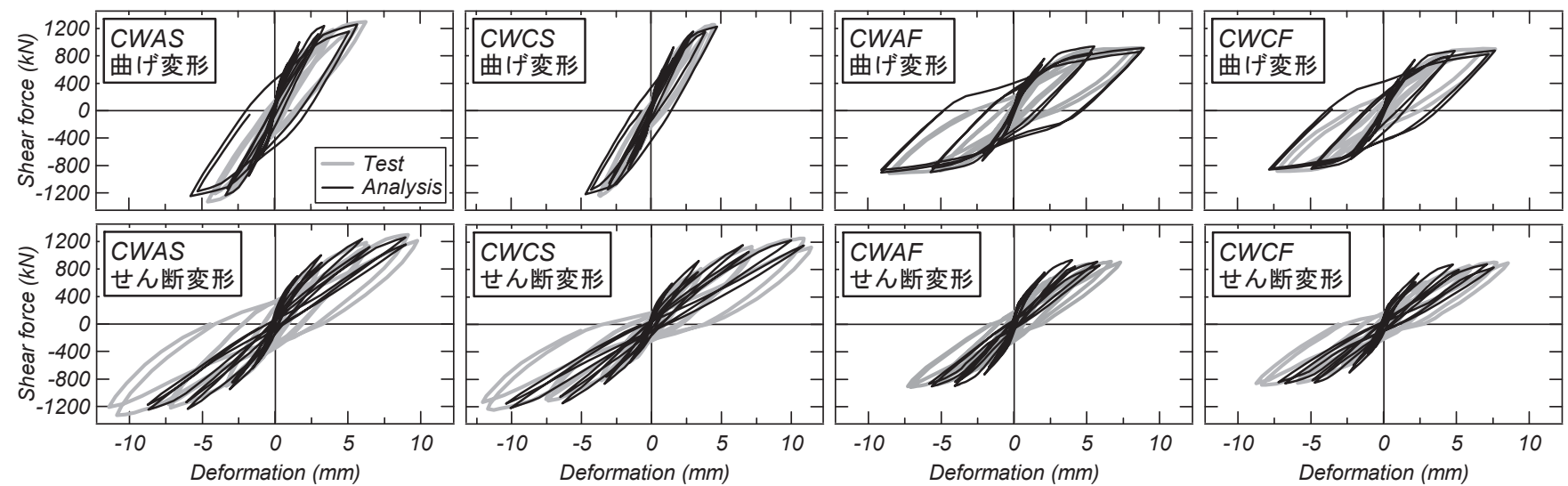

図 10 実験および解析における変形成分の比較（ $\mathrm{R}=0.75 \times 10^{-2} \mathrm{rad}$. の 2 サイクル目まで $)$

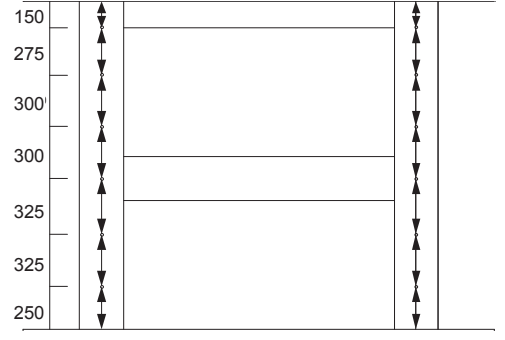

図 11 側柱変位計位置

\section{2 変形成分}

図 10 に $\mathrm{R}=0.75 \times 10^{-2} \mathrm{rad}$.までの実験と解析におけるせん断力一曲 げ変形およびせん断変形成分の履歴特性をそれぞれ示す。実験およ び解析の曲げ変形は高さ方向を 7 分割して測定した側柱の軸方向変 形量から求め (側柱変位計測位置は図 11 参照), せん断変形は全体 変形から曲げ変形を差し引いたものである。

せん断破壊先行型試験体では, 解析の曲げ変形は $\mathrm{R}=0.75 \times 10^{-2} \mathrm{rad}$. の負載荷から実験結果と比べて大きくなる傾向が確認できるが, 実 験結果と解析結果の挙動は概ね一致している。また，載荷サイクル の進行に伴い，せん断変形成分の解析における除荷時の剛性は実験 結果と比べて小さくなる傾向が見られる。すなわち，せん断力一せ 几断変形成分の履歷特性の影響が図 9 に示寸せん断力一部材角関係 の原点指向型の履歴特性に現れたと考えられる。
曲げ降伏先行型試験体では, 解析の曲げ変形は $\mathrm{R}=0.75 \times 10^{-2} \mathrm{rad}$. のサイクルから実験結果と比べて若干大きくなることが認められる。 また，曲げ変形およびせん断変形成分の解析結果における除荷時の 剛性は実験結果と比べて概ね一致することが確認できる。

以上の解析結果から, 本解析モデルにおいて CES 造耐震壁の履歴 特性の包絡線は $\mathrm{R}=0.75 \times 10^{-2} \mathrm{rad}$.まで概ね模擬できたと判断し, 次章 からは本解析結果を用いて耐震壁の内部応力状態について検討を進 める。

\section{5. 内部応力状態}

\section{1 最小主応力分布}

図 12 に $\mathrm{R}=0.75 \times 10^{-2} \mathrm{rad}$. の 1 サイクル目正載荷ピーク時における 耐震壁の最小主応力分布（圧縮応力分布）を示す。最小主応力分布 は図 6 に示す要素分割図の 4 分割した壁板の中央位置を示す。

全ての試験体において 1 層から 2 層にかけて壁板に圧縮ストラッ トが形成されており，圧縮側柱脚部に高い圧縮応力が生じている。 一方，形成された圧縮ストラットの応力のレベルを見ると，せん断 破壊先行型試験体の応力は曲げ降伏先行型試験体と比べて全体的に 高くなることがわかる。

1 層壁板に着目すると，無偏心壁試験体 CWAS および CWAF（図 12(a)と(d)) では, 圧縮側付近の壁板で高い圧縮応力が生じているが, 


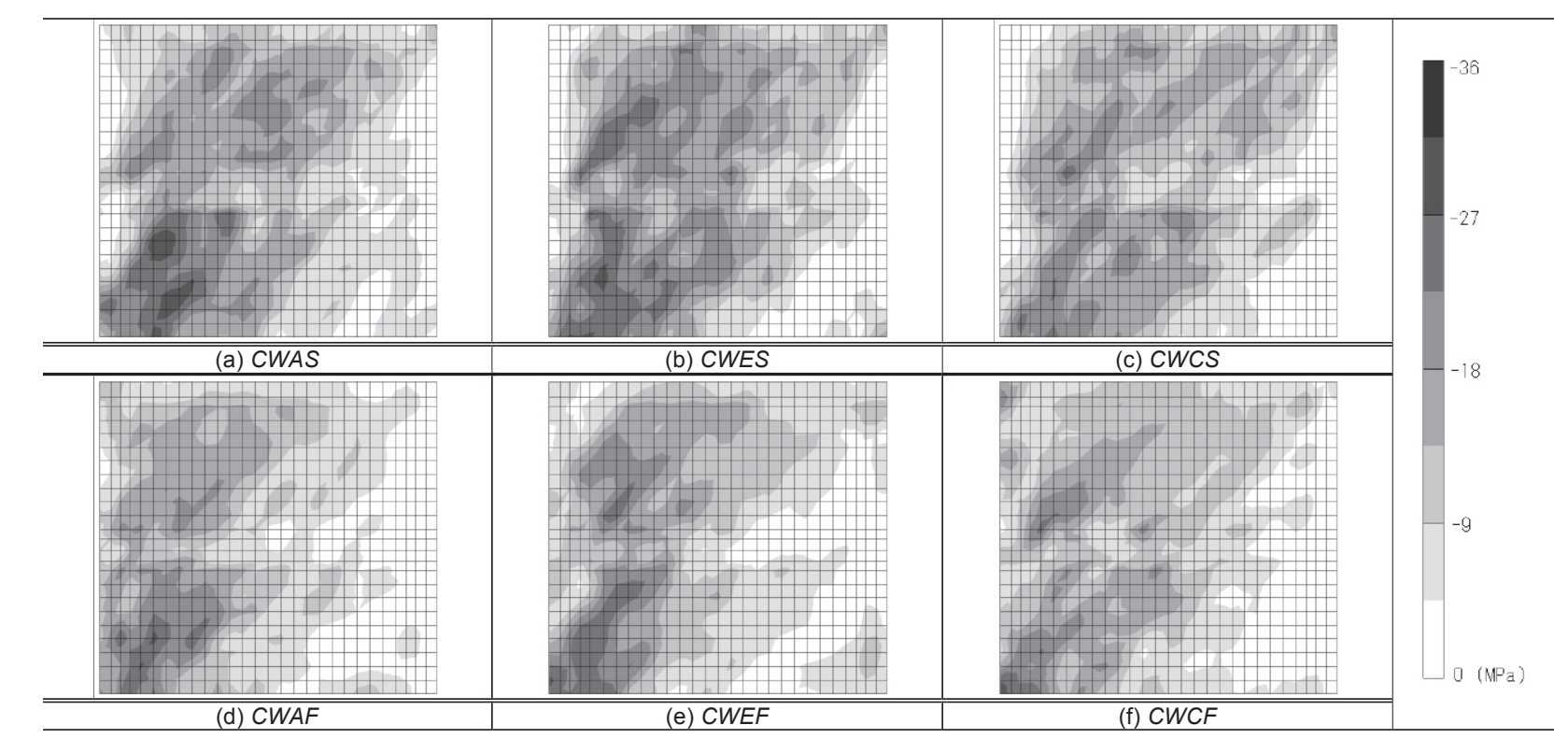

図 12 最小主応力分布 $\left(\mathrm{R}=0.75 \times 10^{-2} \mathrm{rad}\right.$. $)$
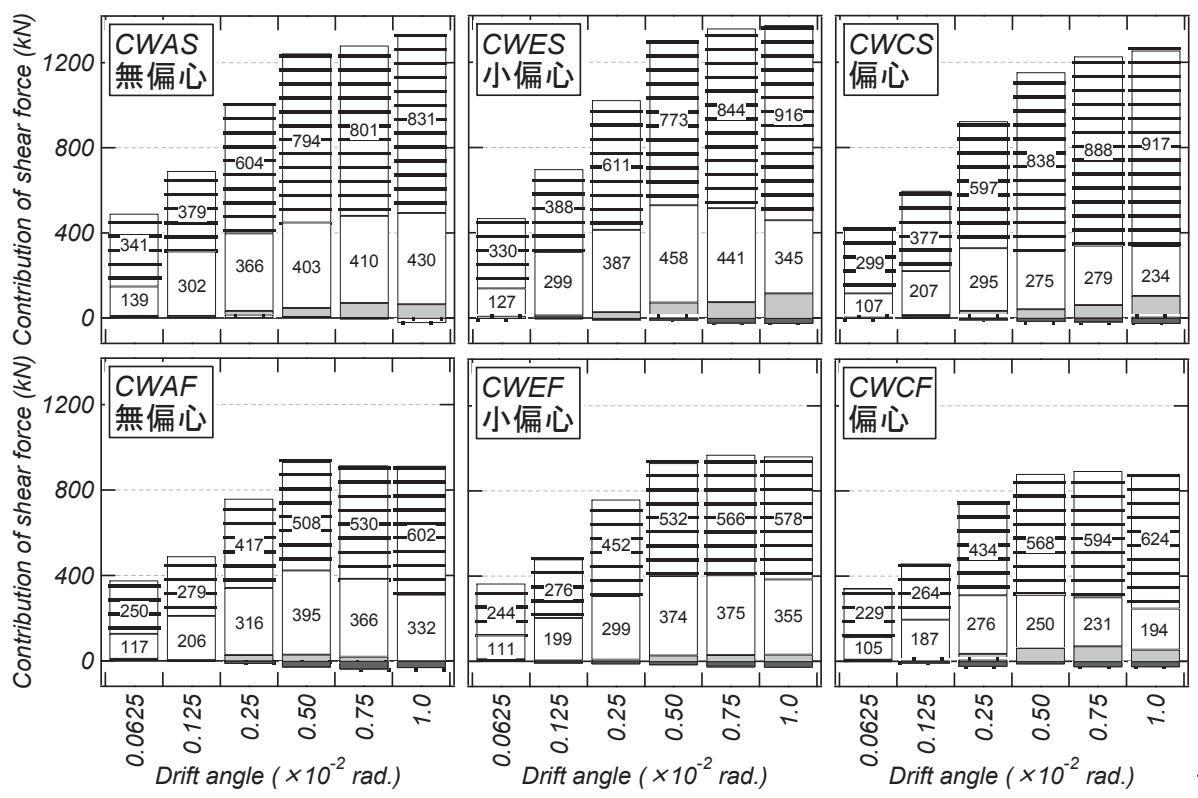

図 13 負担せん断力の推移

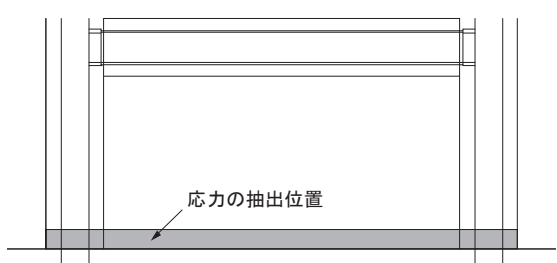

図 14 コンクリートの要素位置

偏心壁試験体 CWCS および CWCF（図 12(c)と(f)）では, 圧縮側壁 板の応力は無偏心壁試験体のものと比べて小さくなることがわかる。 これは, 偏心壁試験体の壁板は無偏心壁試験体と比べて側柱による 拘束の影響が小さいためと考えられる。また，小偏心壁モデルの壁 板は偏心しているものの, 偏心の度合いは偏心壁試験体と比べて小 さく, 小偏心壁モデルの壁板の応力は無偏心壁試験体のものと同程 度になったと考えられる。

\section{2 負担せん断力の推移}

図 13 に各試験体脚部の負担せん断力の推移をそれぞれ示す。負担 せん断力は, 壁板, 圧縮側柱コンクリート, 引張側柱コンクリート, 圧縮側鉄骨および引張側鉄骨に分けて示している。また，負担せん 断力の推移は図 14 に示される位置における結果についてそれぞれ 示している。

全ての試験体において, 壁板および圧縮側柱のコンクリートがせ
し断力の大部分を負担している。各試験体の負担せん断力の推移に ついて見ると，無偏心壁試験体 CWAS および CWAF と小偏心壁モ デル CWES および CWEF では $\mathrm{R}=0.5 \times 10^{-2} \mathrm{rad}$.まで圧縮側コンクリー 卜の負担せん断力の増加が認められるが, 偏心壁試験体 CWCS およ び CWCF では $\mathrm{R}=0.25 \times 10^{-2} \mathrm{rad}$.まで圧縮側コンクリートの負担せん断 力の増加が認められる。また, 負担せん断力の割合について見ると, 全ての部材角において無偏心壁試験体および小偏心壁モデルの圧縮 側柱コンクリートの負担せん断力の割合は偏心壁試験体と比べて大 きくなる傾向が認められ, 壁板の偏心は耐震壁脚部の圧縮側柱コン クリートの負担せん断力に大きく影響を及ぼすことがわかる。

\section{3 コンクリートのせん断応力度分布}

図 15 に $\mathrm{R}=0.5$ および $0.75 \times 10^{-2} \mathrm{rad}$.の 1 サイクル目正載荷ピーク時 の壁板脚部の面内方向せん断応力度分布を示寸。せん断応力度分布 は図 14 に示すコンクリート要素の圧縮側方向の半分を示す。 


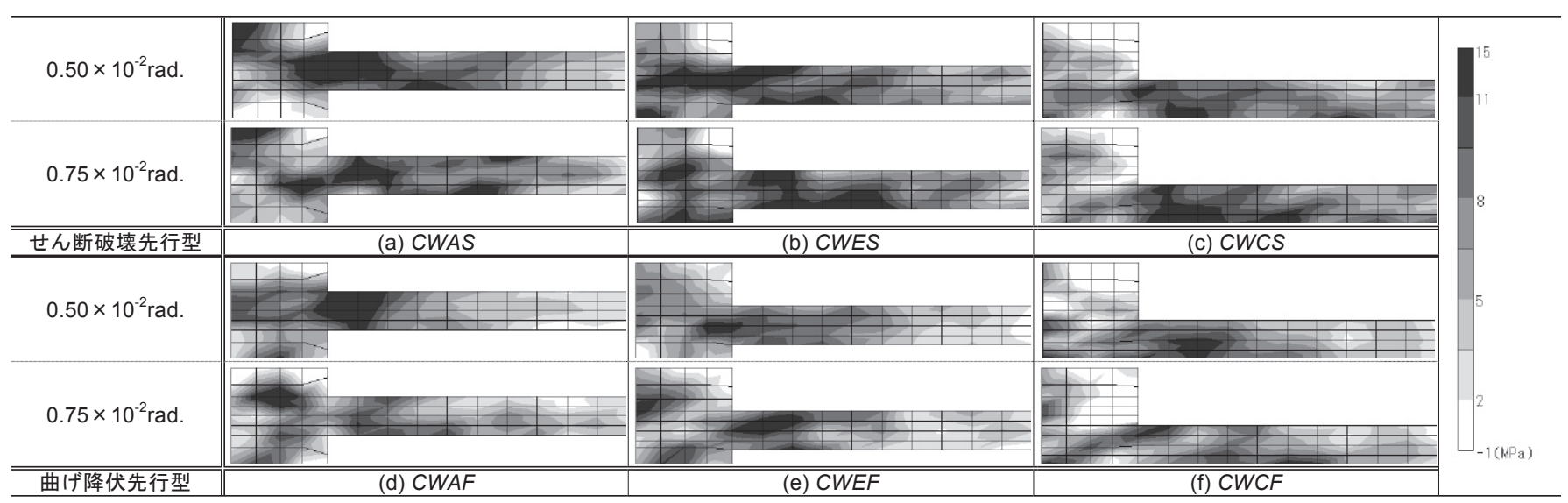

図 15 コンクリートのせん断応力度分布 (上 : $\mathrm{R}=0.50 \times 10^{-2} \mathrm{rad}$., 下 : $\mathrm{R}=0.75 \times 10^{-2} \mathrm{rad}$.)

無偏心壁試験体 CWAS および CWAF（図 15(a)と(d)）では，面外 方向に対象な試験体にも拘らずせん断応力度分布は対象になってい ない。これは, コンクリート要素のひび割れ発生に伴う誤差が原因 と考えられる。

$\mathrm{R}=0.5$ および $0.75 \times 10^{-2} \mathrm{rad}$.に着目寸ると, 無偏心壁試験体 CWAS および CWAF(図 15(a)と(d)) と小偏心壁モデル CWES および CWEF (図 15(b)と(e)) では, せん断応力度は圧縮側柱の広範囲で生じて いることがわかる。一方, 偏心壁試験体 CWCS および CWCF（図 15(c)と(f)）では, 圧縮側柱のせん断応力度は圧縮側柱の北側東部で ほとんど生じていない傾向が認められ, 偏心壁試験体のせん断応力 度の領域は無偏心壁試験体および小偏心壁モデルと比べて狭くなる 傾向が認められる。

このように，偏心壁試験体では，壁板が側柱に偏心して取り付く ため, せん断力は圧縮側柱に伝達され難くなると考えられる。その ため, 圧縮側柱脚部のせん断応力度の生じる領域は無偏心壁試験体 と比べて小さくなる。一方で, 小偏心壁モデルでは, 壁板は側柱に 偏心して取り付くものの, その影響は偏心壁試験体と比べて小さく, 壁板から圧縮側柱脚部にせん断力が良好に伝達するため, 圧縮側柱 脚部のせん断応力度の生じる領域は無偏心壁試験体と比べて同程度 になる。なお，本論における検討は限られた試験体によるものであ り，試験体形状および鉄骨断面などの因子は耐震壁のせん断伝達メ カニズムに少なからず影響を及ぼす可能性があり, 今後の研究課題 としたい。

\section{6. まとめ}

本論では, 壁板が柱に偏心して取り付いた CES 造耐震壁の 3 次元 非線形 FEM 解析を実施し, 解析モデルの妥当性の検討および壁板 の偏心が応力伝達メカニズムに及ぼす影響についての検討を行った。 本研究により得られた知見を以下に示す。

1) 3 次元 FEM 解析モデルによって, CES 造耐震壁の復元力特性 は最大耐力時まで概ね再現することができる。

2) 壁板の配置が側柱中心位置から大きくずれる場合では, 圧縮側 柱の負担せん断力は無偏心壁配置のものと比べて小さく, 壁板 から圧縮側柱脚部にかけてのせん断力伝達性能の低下寸る傾 向が認められ，偏心壁配置の耐震壁のせん断伝達メカニズムは 無偏心壁配置の耐震壁と異なることが確認された。
3) 壁板が偏心配置されている CES 造耐震壁でも，側柱中心位置 が壁板厚の範囲にある場合では, 圧縮側柱の負担せん断力は偏 心壁配置のものと比べて大きく，無偏心壁配置の耐震壁と同程 度のせん断力伝達性能が期待できる。

\section{参考文献}

1) 松井智哉, 溝淵博己, 倉本 洋: H 型鉄骨内蔵 CES 柱の構造実験と FEM 解析，コンクリート工学年次論文集，Vol.32，No.2，pp.1171-1176，2010.7

2) 永田 諭, 松井智哉, 倉本 洋: 鉄骨コンクリート造柱梁接合部の構造 性能に関する基礎研究，コンクリート工学年次論文集，Vol.28，No.2, pp.1267-1272，2006.7

3) 倉本 洋, 松井智哉, 今村岳大, 田口 孝: CES 合成構造平面架構の構 造性能, 日本建築学会構造系論文集, No.629, pp.1103-1110, 2008.7

4) 鈴木 卓, 松井智哉, 倉本 洋: CES 造而震壁の構造性能に及ぼす壁縦 筋の定着状態の影響，コンクリート工学年次論文集，Vol.32，No.2， pp.1189-1194, 2010.7

5) 鈴木 卓, 松井智哉, 倉本 洋 : 壁縦筋の定着方法の異なる CES 造連層 耐震壁の非線形 FEM 解析, 日本建築学会構造系論文集, No.666, pp.1533-1540, 2011.8

6) 鈴木 卓, 岐津幸大, 松井智哉, 倉本 洋 : 壁板が柱に偏心して取り付 いた CES 造耐震壁の構造性能, コンクリート工学年次論文集, Vol.33, No.2, pp.1189-1194, 2011.7

7) 伊藤忠テクノソリューションズ侏：FINAL/V11 HELP，2010.3

8) 長沼一洋: 三軸圧縮応力下のコンクリートの応力〜ひずみ関係, 日本建 築学会構造系論文集, 第 474 号, pp.163-170, 1995.8

9) 出雲淳一, 島 弘, 岡村 甫 : 面内力を受ける鉄筋コンクリート板要素 の解析モデル，コンクリート工学，Vol.25, No.9, pp.134-147, 1987.

10) 長沼一洋, 大久保雅章: 繰返し応力下における鉄筋コンクリート板の解 析モデル，日本建築学会構造系論文集，No.536，pp135-142，2000.10

11）長沼一洋，平面応力場における鉄筋コンクリート板の解析モデル，日本 建築学会構造系論文報告集, 第 421 号, pp.39-48, 1991.3

12) 井本勝慶, 米澤健次, 加藤朝郎, 川里健 : $1 / 4 \mathrm{PCCV}$ の耐圧限界挙動に関 するラウンドロビン解析, コンクリート工学, Vol.41, No.1, pp.153-157, 2003.1

13）三島徹也，山田一宇，前川宏一：正負交番載荷下における鉄筋コンクリ 一トひびわれ面の局所的挙動, 土木学会論文, No.442, V-16, pp.161-170, 1992.2

14）後藤康明, 穴吹拓也, 城 攻: SRC 造内柱梁接合部におけるせん断応力 分担に関する非線形有限要素解析，日本建築学会大会学術講演梗概集， C-1, pp.1089-1090, 2005.9

15）佐藤政勝, 田中祐人：鋼管, $\mathrm{H}$ 型鋼の付着強度に及ぼすコンクリートの 拘束効果について, コンクリート工学年次論文報告集, Vol.15, No.2, 1993.

（2012年 1 月 9 日原稿受理，2012年 8 月 8 日採用決定） 